Jurnal

Kardiologi Indonesia

J Kardiol Indones. 2015;36:22-7

ISSN $0126 / 3773$

Clinical Research

\title{
Polysaccharide Peptide: A promising Anti Inflammation and Anti Oxidant in Atherosclerosis
}

\author{
Indra Prasetya', Ria Ashriyah', Ira Setyawati', Joko Hermawan', Widyo Mahargo', Yunita \\ Leksono', Titin Andri W. ${ }^{2}$, Teuku Heriansyah ${ }^{3}$, Muhammad Aris W. ${ }^{4}$, Dianggan Sargowo ${ }^{1,5}$
}

\footnotetext{
${ }^{1}$ Department of Cardiology and Vascular Medicine, Faculty of Medicine, Brawijaya University / Dr. Saiful Anwar Hospital, Malang, ${ }^{2}$ Department of Nursery, Faculty of Medicine, Brawijaya University, Malang, ${ }^{3} \mathrm{De}-$ partment of Cardiology and Vascular Medicine, Faculty of Medicine, Syiah Kuala University / Dr. Zainoel Abidin Hospital, Banda Aceh, ${ }^{4}$ Department of Pharmacology and Pharmacotherapy, Faculty of Medicine University of Brawijaya, Malang, ${ }^{5}$ Department of Internal Medicine, Faculty of Medicine, Brawijaya University / Dr. Saiful Anwar Hospital, Malang.
}

Background : Heart disease is the leading cause of death for both men and women, but heart disease is preventable and controllable. Ganoderma lucidum is widely used as traditional medicine for centuries particularly in China, Japan, and Korea. Previous study showed antioxidative activity of polysaccharide peptide (PsP) from Genoderma lucidum.

Objective : This study was aimed to evaluate anti-inflammatory and antioxidant effect of polysaccharide peptide (PsP) from Ganoderma lucidum in atherosclerotic rats.

Methods : The atherosclerotic rats were randomly divided into four groups (5 rats each group) : atherosclerotic model with high-fat diet, low dose PsP treated group $(50 \mathrm{mg} / \mathrm{kgBW})$, medium dose PsP treated group (150 mg/ $\mathrm{kgBW})$, high dose PsP treated group (300 mg/kgBW), with normal mice used as a control group. Parameters measured were the level of MDA, SOD, IL - 6 , IL - I0, hsCRP, TNF - $\alpha$, lipid profile and foam cell.

Results : After PsP therapy for 5 weeks, the levels of MDA $(p=0.0 \mathrm{I})$, hsCRP $(p=0.018)$ in rats model of atherosclerosis decrease significantly. PsSP can reduce levels of IL - $6(p=0.933)$ and increase levels of SOD $(p=0.28)$ descriptively at PsP doses I $50 \mathrm{mg} / \mathrm{kgBW}$. While the levels of TNF- $\alpha(p=0.894)$ and IL- IO ( $p=0.98)$ was not affected by administration of PsP. PsP improve the lipid profile by increasing HDL $(p=0.002)$ and lowering total cholesterol $(p=0.04)$. The formation of foam cells $(p=0.024)$ as a marker of atherogenesis significantly decreased by administration of PsP .

Conclusion : PSP can be useful to reduce inflammatory processes and oxidative stress to prevent the process of atherogenesis .

(J Kardiol Indones. 2015;36:22-7)

Keywords: polysaccharide peptide (Ganoderma lucidum), anti inflammation, anti oxidant, cardiovascular disease, atherosclerotic. 


\title{
Peptida Polisakarida: Anti Inflamasi dan Anti Oksidan yang Menjanjikan pada Atherosklerosis
}

\author{
Indra Prasetya', Ria Ashriyah', Ira Setyawati', Joko Hermawan', Widyo Mahargo', \\ Yunita Leksono', Titin Andri W. ${ }^{2}$, Teuku Heriansyah'3 ${ }^{3}$ Muhammad Aris W. ${ }^{4}$, \\ Dianggan Sargowo ${ }^{1,5}$
}

\begin{abstract}
Latar belakang: Penyakit jantung adalah merupakan penyebab kematian utama pada pria dan wanita, akan tetapi penyakit jantung dapat dicegah dan dikotrol. Ganoderma lucidum telah digunakan selama berabad-abad, khususnya di China, Jepang, dan Korea. Pada beberapa penelitian sebelumnya menunjukkan efek antioksidan dari peptida polisakarida yang berasal dari Ganoderma lucidum.

Tujuan: Mengevaluasi efek anti-inflamasi serta anti-oksidan dari peptida polisakarida (PsP) ekstrak Ganoderma lucidum pada tikus yang diberi paparan diet tinggi lemak.

Metode: Tikus aterosklerosis dibagi menjadi empat kelompok (5 tikus masing-masing kelompok) : model aterosklerosis dengan diet tinggi lemak, diberi terapi PsP dosis rendah (50mg/kgBB), dosis sedang (150mg/kgBB), dan dosis tinggi $(300 \mathrm{mg} / \mathrm{kgBB})$, serta kelompok tikus normal sebagai kontrol negatif. Parameter yang diukur adalah kadar MDA, SOD, IL-6, IL-10, hsCRP, TNF- $\alpha$, profil lipid dan juga foam cell.

Hasil: Setelah pemberian terapi PsP selama 5 minggu, kadar MDA ( $\mathrm{p}=0.01)$, hsCRP ( $\mathrm{p}=0.018)$ pada tikus model atherosklerosis dapat turun secara signifikan. Pemberian PsP dapat menurunkan kadar IL-6 ( $\mathrm{p}=0.933$ ) dan meningkatkan kadar SOD ( $\mathrm{p}=0.28)$ secara deskriptif pada dosis PsP $150 \mathrm{mg} / \mathrm{kgBB}$. Sedangkan kadar TNF- $\alpha$ ( $\mathrm{p}=0.894)$ dan IL-10 ( $\mathrm{p}=0.98)$ tidak terpengaruh dengan pemberian PsP. PsP memperbaiki profil lipid dengan meningkatkan kadar HDL ( $\mathrm{p}=0.002)$ dan menurunkan Kholesterol total $(\mathrm{p}=0.04)$. Pembentukan foam cell $(\mathrm{p}=0.024)$ sebagai penanda atherogenesis ternyata menurun secara signifikan dengan pemberian PsP.

Kesimpulan: PsP dapat bermanfaat untuk menurunkan proses inflamasi dan oksidatif stres untuk mencegah proses atherogenesis.
\end{abstract}

(J Kardiol Indones. 2015;36:22-7)

Kata kunci: peptida polisakarida (Ganoderma lucidum), anti-inflamasi, anti-oksidan, penyakit kardiovaskuler, atherosklerosis.

\section{Alamat Korespondensi}

Dr. Indra Prasetya, Departemen Kardiologi dan Kedokteran Vaskuler, Fakultas Kedokteran, Universitas Brawijaya / Rumah Sakit Dr. Saiful Anwar, Malang. Jaksa Agung Suprapto Street, no. 2, Malang 65I II, Indonesia. E-mail: djanggan@yahoo.com.

\section{Introduction}

Heart disease is one of the leading causes of mortality in the world. It is shown that $48 \%$ of deaths in the world 
related with non-infectious diseases, is cardiovascular disease. In 2008, 17.3 million people died from cardiovascular disease, heart attack 7.3 million and 6.2 million due to stroke. ${ }^{1}$

Atherosclerosis is caused by inflammation or chronic inflammation produced by macrophages, polymorfonuclear cells, and his cytokines. ${ }^{2}$

It has recently been developed herbal medicine as complementary therapy on CHD patients including Ganoderma lucidum. Ganoderma lucidum is a favorite ingredient in traditional oriental medicine for centuries. Several studies have shown Ganoderma Lucidum extract useful on CHD, clinically improving clinical complaints, lowering total serum cholesterol, improves ECG and blood pressure.v In addition the study also showed benefits in Scandinavia, extracts of the fungus Saccharomyces cerevisiae wall containing $\beta$-glucan given to patients undergoing $C A B G$, which decreases the inflammatory response and protect the heart from reperfusion injury. ${ }^{4}$ But only limited study focus in effect of Ganoderma lucidum in chronic inflammation and oxidative stress in atherogenesis.

In this study, the authors aims to prove the effect of extracts of Ganoderma lucidum, polysaccharides peptide (PsP) that contains bioactive $\beta$-D-glucan on markers of chronic inflammation and oxidative stress in rat given High Fat Diet (HFD).

\section{Methods}

This study was designed using the experimental method in rats to determine the effect of PsP for the treatment of chronic inflammation process.

This research was conducted at the Central Laboratory of Life Sciences Brawijaya (LSIH) University of Brawijaya, Malang.

Experimental animals in this study were rats (rattus norvegicus) obtained from CV Gamma Scientific Biolab, Malang. Inclusion criteria were male rats, approximately 3 months of age, weight about 150 200 grams, healthy condition and no anatomical abnormalities. While the exclusion criteria are rats had diarrhea during the study period were marked by feces is not formed and or lose weight, dead and sick during the treatment period, rats throughout the study would not eat. Rats drop out if match with exclusion criteria and replaced with other rats in accordance with the inclusion criteria, in order to get the number of rats in accordance with the sample.
PsP made by Sahabat Lingkungan Hidup Surabaya, a biopharmaceutical company. PsP extracted from mycelia of Ganoderma lucidum. PsP is prepared in dry powder form.

A total of 25 rats acclimated with normal food. Then the rats were fed with HFD to make a rat model of atherosclerosis, whereas rats for the control group were given a normal food. After being fed with high fat diet for 8 weeks, the rats were divided randomly into 5 groups: negative control group with normal diet + saline solution as a placebo, a positive control group with HFD (atherosclerosis)+saline solution as a placebo, then the group treated with HFD+saline containing 50, 150, $300 \mathrm{mg} / \mathrm{kg}$ PsP for 5 weeks each group consisted of 5 rats. Diets are made every day given as a daily diet of $50 \mathrm{~g} / \mathrm{rat} /$ day. Diet gave at the same time during the day at 12.00-14.00. A normal feed consisting of chicken feed / Pars (with water content, protein, fat, fiber, ash, Ca, phosphorus, antibiotic, coccidiostat) $66.6 \%$ and $33.4 \%$ wheat flour.

Measurement of IL-6, IL-10, TNF- $\alpha$, hsCRP, MDA, SOD, lipid profile and foam cells in experimental animals by taking blood or organs of experimental animals. We measured Inflammation marker (IL-6, IL10 , TNF- $\alpha$, hsCRP), Oxydative Stress marker (MDA, SOD) with ELISA kits and foam cell measurements with hematoxylin or HE.

\section{Statistical Analysis}

The data were analyzed with the SPSS version 7.0 software. Descriptive analysis that will be presented include the mean value, standard deviation, the lower and upper $95 \%$ confidence interval, and the minimum value of the maximum temptation. Bivariat analysis using Oneway Anova was used to identify significant difference between at least the two treatment groups in all parameters. Post Hoc Test Duncan test will be done if one way anova showed significant difference $(\mathrm{p}<0.005)$ between at least two treatment groups to identify doses of PsP that affects the parameters.

\section{Results}

This study was conducted to determine the effect of poly- saccharides Peptide (PsP) in inhibiting the formation of atherosclerosis in atherosclerosis rats induced by HFD. The mechanism of inhibition of the formation of atherosclerosis identified by 
identifying the parameters as follows: MDA, SOD (Oxydative Stress marker) IL-6, hsCRP, TNF- $\alpha$, IL-10 (Inflammation Marker), Total Cholesterol, Triglycerides, Low Density Lipid (LDL), High Density Lipid (HDL) (Lipid Profile), and foam cell.

\section{Oxydative Stress Marker}

Lowest MDA levels were observed in the normal group. While the highest MDA levels found in atherosclerotic group, Descriptively, an increase dose of the PSP having an inclination to reduce levels of MDA. PsP at dose $300 \mathrm{mgkgBW}$ significantly lowered

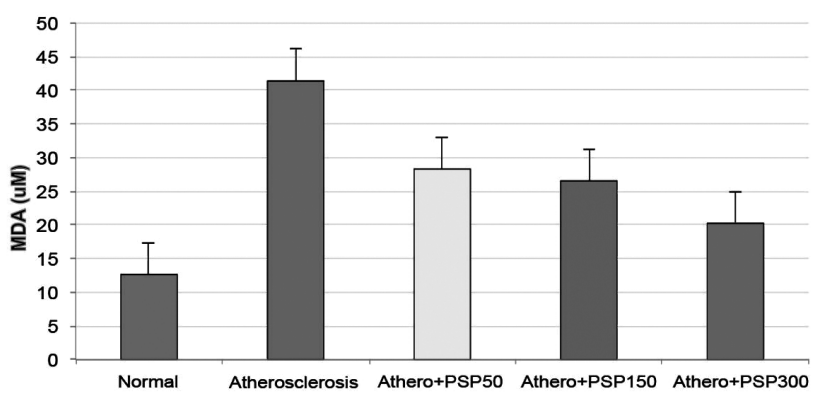

Figure 1. MDA Levels (uM) on HFD Induced Rats.

MDA level ( $\mathrm{p}=0.001)$ (Figure 1).

PsP showed no correlation with level of SOD descriptively and also of bivariate analysis $(\mathrm{p}=0.280)$. Lowest SOD observed in the experimental results are in atherosclerosis group+PSP $50 \mathrm{mg}$. While the highest levels of SOD found in the atherosclerotic group + PSP $150 \mathrm{mg}$.

\section{Inflammation Marker}

IL-6 level were descriptively reduced with PsP dose $150 \mathrm{mg} / \mathrm{kgBW}$, the lowest experimental results are in atherosclerosis group + PSP $150 \mathrm{mg}$. Bivariate analysis PsP has no correlation with IL-6 level $(\mathrm{p}=0.933)$.

$\mathrm{PsP}$ showed significantly reduced of hsCRp $(p=0,018)$ in the treatment groups especially in dose $50 \mathrm{mg} / \mathrm{kgBW}$ (Figure 2).

TNF- $\alpha$ and IL-10 levels were not correlated with PsP treatment ( $\mathrm{p}=0.894$ and $\mathrm{p}=0.98$ respectively).

\section{Lipid Profile}

PsP treatment decreased cholesterol total level (Figure

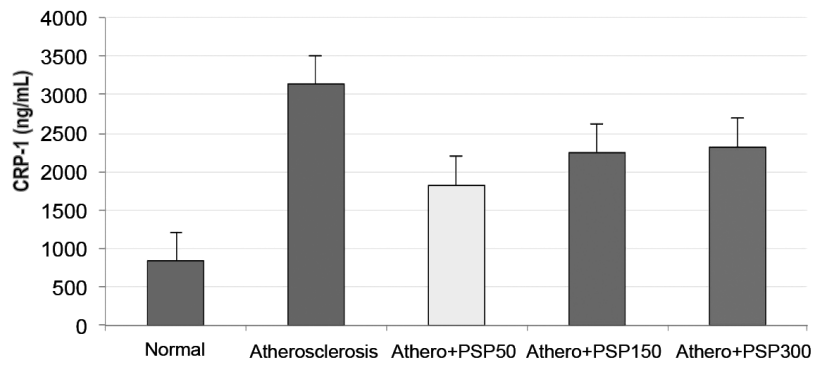

Figure 2. hsCRP Levels (ng/mL) on HFD Induced Rats.

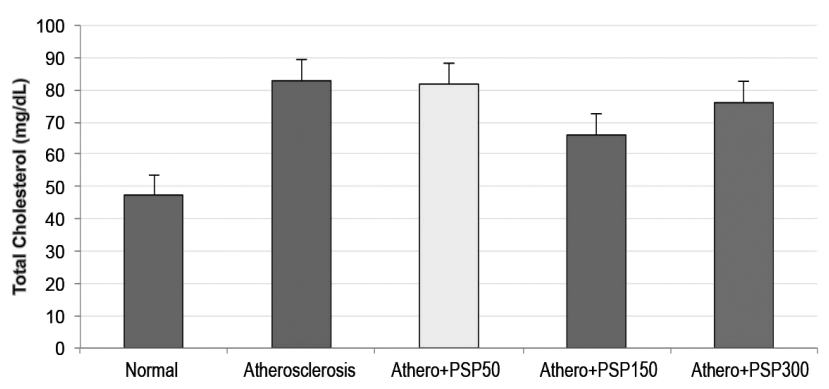

Figure 3. Total Cholesterol Levels (mg/dl) on HFD Induced Rats.

3 ) and increased HDL level significantly $(\mathrm{p}=0.04$ and $\mathrm{p}=0.002$ respectively) at PsP dose $50,150,300 \mathrm{mg} /$ $\mathrm{kgBW}$, but no correlation with LDL and triglyceride level $(\mathrm{p}=0.129$ and $\mathrm{p}=0.340)$.

\section{Foam Cell}

PsP decreased foam cell count significantly $(\mathrm{p}=0.024)$ at PsP dose $300 \mathrm{mg} / \mathrm{kgBW}$ (Figure 4).

Based on these results there are dose differences to get results as expected. To get the reduction in MDA levels close to normal until the required dose $300 \mathrm{mg} /$ $\mathrm{kgBB}$. As for getting the lowest levels of hsCRP is giving $50 \mathrm{mg} / \mathrm{kgBB}$ PSP.

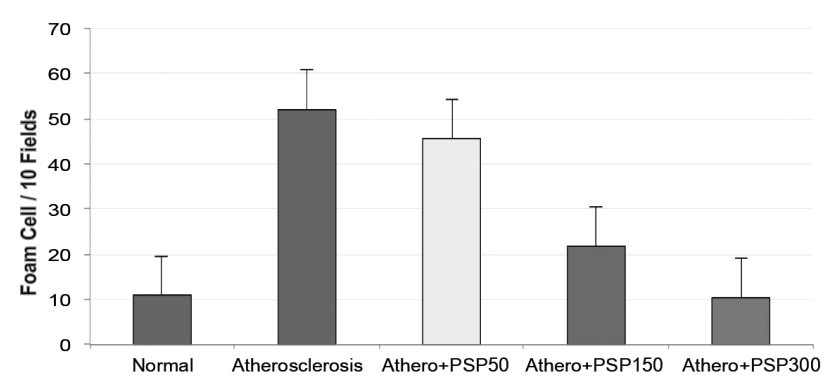

Figure 4. Foam Cell I 10 Fields on HFD Induced Rats. 
In this study also showed that the PSP could correct lipid profiles and reduce the levels of foam cells. To get the required reduction in total cholesterol need PSP $150 \mathrm{mg} / \mathrm{kgBW}$ or $300 \mathrm{mg} / \mathrm{kgBW}$, while to be able to increase HDL can use $50 \mathrm{mg} / \mathrm{kgBW}$ dose, $150 \mathrm{mg} / \mathrm{kgBW}$ or $300 \mathrm{mg} / \mathrm{kgBW}$. As for lowering the number of foam cells to near normal requires a PSP with $300 \mathrm{mg} / \mathrm{kgBB}$ dose.

\section{Discussion}

Ganoderma lucidum has been used since hundreds of years ago in various countries in the world, but the effectiveness and side effects is still in ongoing research. Limited study focus in the effect of Ganoderma lucidum in atherogenesis especially in chronic inflammation, to our knowledge, we conduct the first in this field.

In the study, presented MDA level showed atherosclerotic rats given PSP $300 \mathrm{mg} / \mathrm{kgBW}$ group was significantly different to the normal rats. Interestingly in our research PsP can't increase significantly SOD level ( $\mathrm{p}=0.280)$ although PsP treatment at dose $150 \mathrm{mg} /$ $\mathrm{kgBW}$ gave the highest effect in increasing SOD, which means higher than normal and atherosclerosis groups. It shows that treatment of PsP can be used as anti oxidant to reduce oxidative stress, although statistically SOD not significantly increased. This result is consistent with previous studies. Galor et al, in 2004 in healthy individuals given showed no significant difference in MDA levels between the placebo and treatment groups. ${ }^{5}$ PSP can increase antioxidant defense systems by increasing the activity of SOD in the body which are composed of antioxidant enzymes that play a role of antioxidant nutrients to protect from oxidative stress. In principle antioxidant enzymes including SOD, GPX and CAT, SOD which catalyzes dysmutase superoxide into oxygen and hydrogen peroxidation..$^{6-8}$

There were conflicting result in our study in inflammation marker. Descriptively, giving $150 \mathrm{mg}$ PSP can reduce levels of IL- 6 and lower levels of IL- 6 than atherosclerosis rats. And there are significant differences in the levels of inflammatory cytokines hsCRP between the negative control group, atherosclerosis, and the treatment group were treated with PsP. In the group treated with a dose of $50 \mathrm{mg}$ PSP turns hsCRP levels of hsCRP levels nearly equivalent to the negative control group, whereas if the dose is increased to $150 \mathrm{mg}$ or $300 \mathrm{mg}$ not further lower hsCRP levels. But PsP administration seems has no role in affecting level of TNF- $\alpha$ and IL-10. Since IL-10 is an anti inflammation marker, our study showed reversed result, whereas normal rat has higher IL-10 level than treatment group.

Previous studies also reveals conflicting result. Galor research, at 2004 in healthy individuals no significant difference in hsCRP levels between the placebo and treatment groups. ${ }^{5}$ Li's research in 2007, in a population of patients suffering from rheumatoid arthritis (RA) with disease-modifying antirheumatic therapy drugs (DMARDs) eg hydroxychloroquine, sulfasalazine, methotrexate, and leflunomide, also showed no difference CRP level between placebo groups were given additional therapy extract ganoderma $4 \mathrm{~g}$ in combination with other herbs for the treatment of 24 weeks. ${ }^{9}$ Several studies also show different result in different design. Ganoderma lucidum increases IL-10 level ${ }^{10-12}$ increases TNF- $\alpha^{13}$ and no correlation with IL-6 level in cancer patients. ${ }^{14}$ But none of the previous studies focus on inflammatory aspect of atherosclerosis.

In this study, administration of PsP in rats by exposure to high fat diet, the fix the lipid profile. Blood cholesterol and HDL levels found statistically significant differences ( $\mathrm{p}=0.04$ and $\mathrm{p}=0.02$ respectively) between treatment groups by administering doses of PSP 50, 150 and $300 \mathrm{mg} / \mathrm{kgBW}$. Li, 2011 on research on rats model of streptozotocin-induced diabetes mellitus also shows the effect antihiperglikemia and anticholesterol-emia. ${ }^{9}$ These results are in contrast to studies of Seto, et al 2009 in obese diabetic rats models $+\mathrm{db} /+\mathrm{db}$ Ganoderma lucidum treated for 4 weeks, did not give the effect of anti- dyslipidemia, lipid profile picture does not improve after administration of Ganoderma lucidum. ${ }^{15}$

Atherogenesis is clearly inhibited with PsP treatment. Foam cell, results of chronic inflammation and oxidative stress decreased significantly $(\mathrm{p}=0.000)$. Giving PSP with increasing doses with optimum dose $300 \mathrm{mg} / \mathrm{kgBB}$ tend to be followed by a decline seen the average number of Foam Cell. This result sthrengtens study by You and Lin in 2002, showed that Ganoderma lucidum polysaccharides peptide can inhibit foam cell formation and necrosis of macrophages. ${ }^{16}$

Limitation of this study is conflicting results especially in marker of inflammation probably due to short duration ( 5 weeks) of treatment of PsP, whereas other studies usually used at least 8 weeks of treatment. ${ }^{17}$ Also, PsP administration given at $9^{\text {th }}$ week, after 8 weeks rats fed with HFD, means chronic inflammation and oxidative stress is longer than 
treatment given. Probably that PsP is more useful as prevention than treatment.

\section{Conclusions}

PsP administration at dose $50,150,300 \mathrm{mg} / \mathrm{kgBW}$ is a promising prevention or treatment as anti inflammation and anti oxidant thus inhibiting atherogenesis in CHD.

Further research is needed to evaluate safety and efficacy of PsP in human by conducting toxicity and cohort study.

\section{Acknowledgements}

We acknowledge the Sahabat Lingkungan Hidup Surabaya for preparing the PsP extract of Ganoderma lucidum. And this study was funded by Direktorat Pendidikan Tinggi through Brawijaya University Indonesia.

\section{References}

1. Go AS, Mozaffarian D, Roger VL, Emelia J. Benjamin, Berry JD, Blaha MJ. Heart Disease and Stroke Statistics—2014 Update. Circulation Journal. 2013;129(e28-e292).

2. Sprague A, Khalil R. Inflammatory Cytokines in Vascular Dysfunction and Vascular Disease. Biochem Pharmacol. 2009;78(6):539 - 52.

3. Yihuai G, Chen G, Xihu D, Jingxian Y, Shufeng Z. A Phase I/ II Study of Ling Zhi Ganoderma lucidum (W Curt.: fr.) lloyid (Aphyllophoromycetideae) extract in patients with coronary heart disease. International Journal of Medicinal mushrooms. 2004;6:327 - 34 .

4. Xu Z, Chen X, Zhong Z, Chen L, all e. Ganoderma lucidum polysaccharides : immunomodulation and potential anti-tumor activities. Am J Chin Med. 2011;39(1):15 - 27.

5. Wachtel-Galor S, Tomlinson B, Benzie IFF. Ganoderma lucidum ('Lingzhi'), a Chinese medicinal mushroom: biomarker responses in a controlled human supplementation study. British Journal of Nutrition. 2004;91:263 - 9.

6. Zhonghui Z, Xiaowei Z, Fang F. Ganoderma lucidum polysaccharides supplementation attenuates exercise-induced oxidative stress in skeletal muscle of mice. Saudi Journal of Biological Sciences. 2013.

7. Pan D, Zhang D, Wu J, Chen C, Xu Z. Antidiabetic, Antihyperlipidemic and Antioxidant Activities of a Novel Proteoglycan from Ganoderm Lucidum Fruiting Bodies on $\mathrm{db} / \mathrm{db}$ Mice and the Possible Mechanism. PLoS ONE. 2013;8(7):e68332.

8. Oluba OM, Onyeneke EC, Ojieh GC, Idonije BO, Ojiezeh TI. Hepatoprotective Potential of Aqueous Extract of Ganoderma lucidum Against Carbon Tetrachloride Intoxication in Rats. Der Pharmacia Lettre. 2010;2(4):432-9.

9. Li F, Zhang Y, Zhong Z. Antihyperglycemic Effect of Ganoderma lucidum Polysaccharides on Streptozotocin-Induced Diabetic Mice. Int J Mol Sci. 2011;12:6135-45.

10. Lin YL, Liang YC, Lee SS, Chiang BL. Polysaccharide purified from Ganoderma lucidum induced activation and maturation of human monocyte-derived dendritic cells by the NF-B and p38 mitogen-activated protein kinase pathways. Journal of Leukocyte Biology. 2005:78.

11. Sun LX. Ganoderma lucidum polysaccharides antagonize the suppression on lymphocytes induced by culture supernatants of B16F10 melanoma cells. J Pharm Pharmacol. 2011;63(5):72535.

12. Futrakul N. Ganoderma lucidum suppresses endothelial cell cytotoxicity and proteinuria in persistent proteinuric focal segmental glomerulosclerosis (FSGS) nephrosis. Clin Hemorheol Microcirc. 2004;31(4):267-72.

13. Cui XY. Extract of Ganoderma lucidum prolongs sleep time in rats. J Ethnopharmacol. 2012;139(3):796-800.

14. Gao Y. Effects of Water-Soluble Ganoderma lucidum Polysaccharides on the Immune Functions of Patients with Advanced Lung Cancer. Journal of Medicinal Food. 2005;8(2):159-68.

15. Seto SW, Lam TY, Tam HL, Au AL, Chan SW, Wu JH, et al. Novel hypoglycemic effects of Ganoderma lucidum waterextract in obese/diabetic $(+\mathrm{db} /+\mathrm{db})$ mice. Phytomedicine : international journal of phytotherapy and phytopharmacology. 2009;16(5):426-36.

16. You YH, Lin ZB. Protective effects of Ganoderma lucidum polysaccharides peptide on injury of macrophages induced by reactive oxygen species. Acta pharmacologica Sinica. 2002;23(9):787-91.

17. Meng G, Zhu H, Yang S, Wu F, Zheng H, Chen E, et al. Attenuating effects of Ganoderma lucidum polysaccharides on myocardial collagen cross-linking relates to advanced glycation end product and antioxidant enzymes in high-fat-diet and streptozotocin-induced diabetic rats. Carbohydrate Polymers. 2011;84(1):180-5. 